\title{
Potential use of Mucuna bracteata as a Cover Crop for Coconut Plantations in the Low Country Intermediate Zone of Sri Lanka
}

\author{
H.M.P.M. Herath ${ }^{1}$, H.M.I.K. Herath ${ }^{1,{ }^{*}}$ and W.M. Ratnayake ${ }^{2}$
}

\begin{abstract}
Cover crops provide a wide range of ecological and environmental benefits. Mucuna bracteata is one of the leguminous creepers which has superior characteristics such as fast growth, high nitrogen fixation ability, high biomass production, and free from pest and diseases. While this plant has recently been used as a cover crop in rubber plantations in the Wet Zone of Sri Lanka, it has not been tested under coconut cultivation in the Intermediate Zone. Therefore, this study aimed to assess the suitability of Mucuna bracteata as a cover crop in coconut plantation in the Low Country Intermediate Zone of Sri Lanka. Four treatments tested in the experiment were, T1 - Mucuna bracteata planted in two rows, T2 - Mucuna bracteata planted in three rows, T3 - Mucuna bracteata planted in four rows in center of square under coconut cultivation and T4 - Coconut without cover crop (control). The treatments were arranged in a randomized complete block design with four replicates. Soil chemical and physical properties were analyzed at $5 \mathrm{~cm}-25 \mathrm{~cm}$ depth. The ground cover, weed density and total biomass production were also evaluated in different planting systems. The highest ground coverage and the lowest weed density were observed in coconut with Mucuna bracteata in three rows at 75 days after field establishment. Mucuna bracteata planted
\end{abstract}

\footnotetext{
${ }^{1}$ Department of Plantation Management, Faculty of Agriculture and Plantation Management, Wayamba University of Sri Lanka, Makandura, Gonawila (NWP), 60170, Sri Lanka

${ }^{2}$ Coconut Development Training Center, Coconut Cultivation Board, Bandiruppuwa estate, Lunuwila, Sri Lanka

*indikaherath@wyb.ac.lk
}

plots had significantly lower bulk density, higher organic carbon content than the control and there was no significant bracteata planted in three rows is the most suitable planting method being able to give better ground cover, lower soil bulk density and higher soil nitrogen than other treatments. According to the results of the study, it can be concluded that Mucuna bracteata could be well grown as a cover crop under coconut in the Intermediate Zone of Sri Lanka. Also, it can be suggested that Coconut with Mucuna bracteata planted in three rows is the most suitable planting method being able to give better ground cover, lower soil bulk density and higher soil nitrogen than other treatments.

Keywords: Coconut plantation, Cover crop, Soil quality, Weed control

\section{INTRODUCTION}

Coconut (Cocos nucifera L.) is the most widely grown plantation crop in Sri Lanka. It covers more than 440,500 hectares of land in both estate sector and smallholders' sector in Sri Lanka. Coconut is mainly cultivated in Low country Intermediate Zone and Wet Zone in Sri Lanka. The current contribution by coconut sector to the Sri Lankan Gross Domestic Production (GDP) is $0.6 \%$ (Anon, 2017).

Coconut is mainly a rain-fed plantation crop and it requires a regular supply of water to maintain its growth and nut production. The drought condition causes a 
severe impact on coconut production in major coconut growing areas such as Kurunegala, Puttalum and Gampaha. During the drought, due to the soil moisture stress, the cells of the absorption zone of coconut roots become inactive adversely affecting the water and nutrient absorption processes (Vidhana- Arachchi et al., 1996; Vidhana-Arachchi et al., 2000). Soil moisture stress also retards growth of young palm, delays flower initiation, increases button nut and immature nuts fall and reduces the nut size as well as number of nuts (Abeywardena, 1971). Therefore, soil moisture conservation becomes one of the major factors that should be considered under coconut cultivation.

Most of the coconut lands which are concentrated in the Low Country Iintermediate Zone and Wet Zone are flat or have a gentle slope. Still, due to the heavy water flow during intensive rains, soil can be eroded in these areas. Furthermore, as a result of continuous cultivation, soil nutrient content has been declined leading to deterioration of soil quality. Therefore, practice of soil and moisture conservation method for coconut plantation has become essential.

Canopy structure of coconut palm requires wide spacing between palms allowing the incident of high amount of sunlight to the ground. This condition promotes weed growth creating a competition with coconut for soil moisture and nutrients in the coconut plantation (Senarathne and Gunathilake, 2010). To avoid the reduction of nut yield, a proper weed management program has to be practiced.

As a solution to most of these problems, cover crops can be established and maintained under coconut plantations. Cover crops provide a wide range of ecological and environmental benefits. They prevent soil erosion by providing ground cover building up soil aggregates by using organic matter and roots exudates. It also improves the soil structure, aggregate stability, water holding capacity like soil physical conditions and reduces the leaching of nutrients. Furthermore, it conserves soil moisture by acting as a mulch and reducing evaporation and increasing infiltration (Samarappuli, 1992). In addition, cover crops suppress weeds and minimize the pest and diseases problems by providing habitat for beneficial organisms and natural enemies. Hence, it may helpful to reduce the need for herbicides and insecticides.

A good cover crop should have characteristics such as easiness to propagate, rapid rate of growth and being able to cover the soil within a short period of time, and resistance against pests and diseases. If the cover crop can fix nitrogen from the air and provide it to the soil, it is considered as an additional advantage.

Mucuna bracteata is one of the leguminous creepers which has a potential to be used as a cover crop. It is native to Kerala, South India and has reported to have a fast growth, maximum nitrogen fixation, high drought tolerance, high biomass 
production, free from pest and diseases, effectively prevent soil erosion and prevent weed growth (Mathews, 1998; Samarappuli et al., 2004).

Mucuna brateata is already used as a cover crop in rubber plantation in Sri Lanka (Samarappuli et al., 2003) and oil palm plantation in Malaysia (Samedani et al., 2015). However, it has not been tested under coconut cultivation in Sri Lanka yet.

Therefore, the objective of this study was to assess the potential of Mucuna bracteata as a cover crop in coconut plantation in the Low Country Intermediate Zone of Sri Lanka. The suitability was assessed in terms of improving soil properties and surface characteristics including ground cover and weed control.

\section{MATERIALS AND METHODS Experimental Site}

The study was conducted in the Low Country Intermediate Zone (IL 1), North Western Province of Sri Lanka. The experiment was established under 20 - 25 year old coconut plantation on red yellow podzolic soil (FAO: Ferric Plinthosols).

\section{Experimental Design and Treatments}

The following four treatments were arranged in a randomized complete block design (RCBD) with four replications. The treatments were randomly arranged to the plots in each block.
- T1 - Mucuna brateata planted in two rows in center of square under coconut cultivation

- $\mathrm{T} 2$-Mucuna brateata planted in three rows in center of square under coconut cultivation

- T3 - Mucuna brateata planted in four rows in center of square under coconut cultivation

- T4 - Coconut without cover crop (control)

\section{Establishment of Treatments}

Nursery was prepared inside the net house conditions and seeds were sown at $1-2 \mathrm{~cm}$ depth into polybags of size $7 \mathrm{~cm} \times 15 \mathrm{~cm}$. Polybags were filled with top soil, sand and organic matter. For better germination, polybags were kept in $50 \%$ shade for two weeks and after that they were exposed to direct sunlight.

Mucuna bracteata seedlings were transplanted in the field after four weeks. The land was ploughed and sixteen beds were prepared. The size of each bed was 4.5 $\mathrm{m} \times 3.6 \mathrm{~m}$. Planting was done with spacing of $1.2 \mathrm{~m} \times 0.9 \mathrm{~m}$ (Figures 1, 2 and 3).

\section{Parameters Measured}

Soil samples were collected for chemical and physical analysis from three different places in each field at $5 \mathrm{~cm}-25 \mathrm{~cm}$ depth initially and after 75 days of transplanting. 


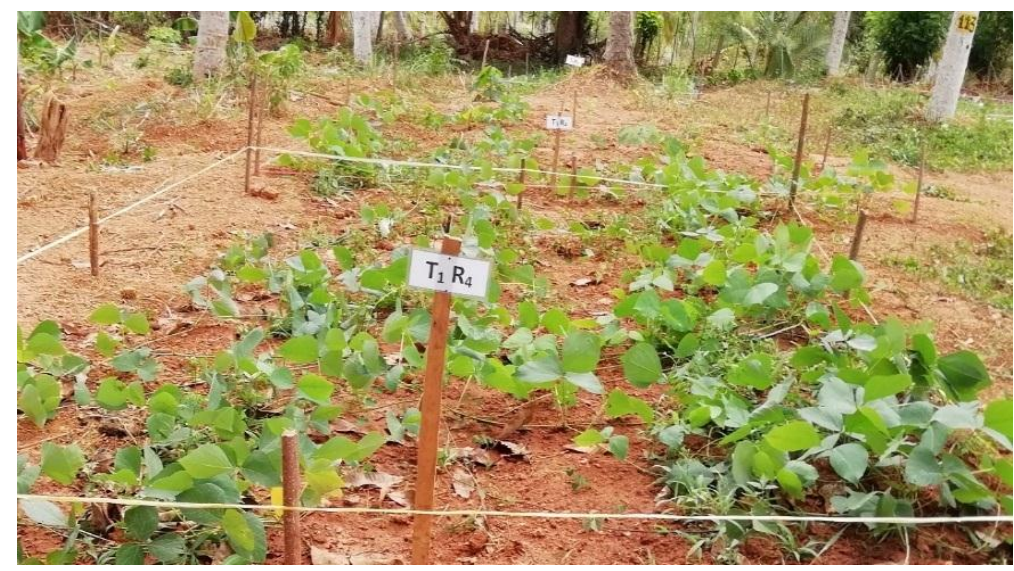

Figure 1. Coconut with Mucuna brateata planted in two rows (T1) in the center of square of coconut (40 days after field planting)

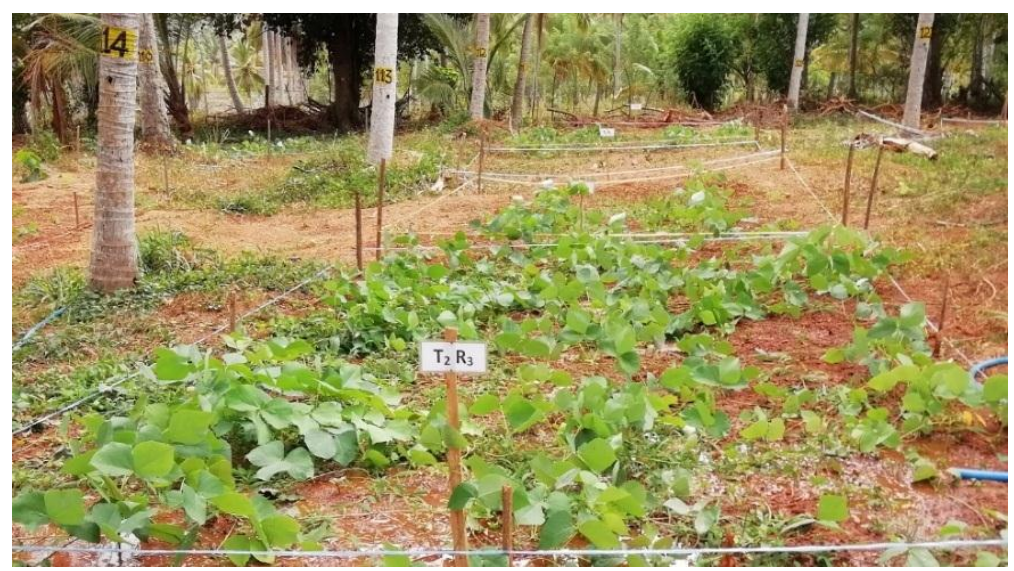

Figure 2. Coconut with Mucuna brateata planted in three rows (T2) in the center of square of coconut (40 days after field planting)

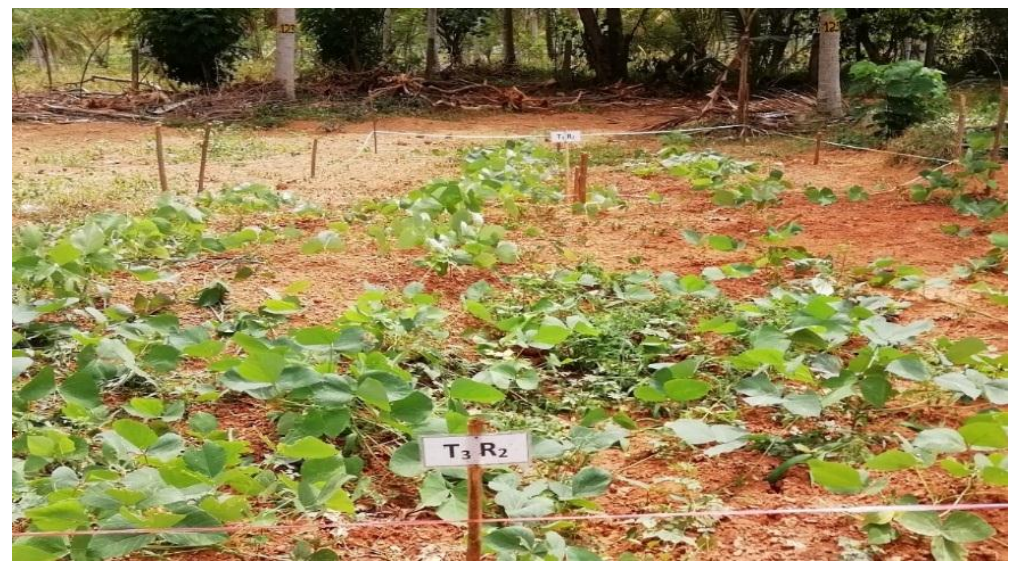

Figure 3. Coconut with Mucuna brateata planted in four rows (T3) in the center of square of coconut (40 days after field planting) 
Soil organic carbon was analyzed by using Walkey and Black method (Nelson and Sommers,1982), total soil nitrogen by Kjeldahl method (Bremner and Mulvaney, 1982), available phosphorous by Olsen bicarbonate method (Olsen et al., 1954), bulk density by core sample method (Blake and Hartge,1986) and soil $\mathrm{pH}$ by using a glass electrode.

Weed density was measured by randomly placing a $1 \mathrm{~m}^{2}$ quadrant in each experimental plot at one month intervals. Ground cover and total biomass were taken 75 days after field establishment by randomly placing a $1 \mathrm{~m}^{2}$ quadrant.

\section{Statistical Analysis}

Data were analyzed using General Linear Model (GLM) followed by Least Significant Difference (LSD) mean separation method and presented means \pm SD with $95 \%$ confident interval using SAS software (version 9.4).

\section{RESULTS AND DISCUSSION \\ Initial Soil Properties}

Initial soil properties show that soils of the experimental site are slightly acidic and have very low organic carbon content (Table 1). However, the soil has higher level of soil phosphorus.

\section{Total Biomass Production}

Total biomass production indicates the amount of litter that is added to the soil. According to the results at 75 days after establishment of cover crop, T2 recorded maximum dry matter production while minimum dry matter production was recorded by $\mathrm{T} 1$ (Table 2). When considering $\mathrm{T} 2$ and $\mathrm{T} 3$, there was no statistically significant difference between the two treatments.

Table 1. Physical and chemical properties of soil before planting

\begin{tabular}{ll}
\hline Parameter & Value \\
\hline Bulk Density $\left(\mathrm{Mg} / \mathrm{m}^{3}\right)$ & $1.42 \pm 0.03$ \\
Organic Carbon $(\%)$ & $0.87 \pm 0.05$ \\
Soil pH & $5.16 \pm 0.11$ \\
Total Nitrogen $(\%)$ & $0.19 \pm 0.04$ \\
$\begin{array}{l}\text { Available Phosphorus } \\
(\mathrm{ppm})\end{array}$ & $49.79 \pm 14.93$ \\
\hline
\end{tabular}

Table 2. Total biomass production (75 days after field establishment)

\begin{tabular}{cccc}
\hline Treatments & $\begin{array}{l}\text { Fresh } \\
\text { Weight } \\
\left(\mathbf{g} / \mathbf{m}^{\mathbf{2}}\right)\end{array}$ & $\begin{array}{l}\text { Dry } \\
\text { Weight } \\
\left(\mathbf{g} / \mathbf{m}^{\mathbf{2}}\right)\end{array}$ & $\begin{array}{l}\text { Dry } \\
\text { Weight } \\
(\mathbf{t} / \mathbf{h a})\end{array}$ \\
\hline T1 (2 rows) & $254.68^{\mathrm{a}}$ & $54.02^{\mathrm{a}}$ & 0.54 \\
T2 (3 rows) & $945.84^{\mathrm{b}}$ & $167.39^{\mathrm{b}}$ & 1.67 \\
T3 (4 rows) & $915.67^{\mathrm{b}}$ & $161.13^{\mathrm{b}}$ & 1.61 \\
T4 (control) & - & - & - \\
\hline
\end{tabular}

Means with different letters within the same column represent significant differences at $p<0.05$ level; $T 1-$ Coconut with M. bracteata in 2 rows, T2 - Coconut with M. bracteata in 3 rows, T3 - Coconut with M. bracteata in 4 rows, T4 - Control/ Coconut without M. bracteata

\section{Weed Density}

Weeds compete with coconut for soil moisture and nutrients and cause significant losses in terms of nut yield. The cover crop Mucuna bracteata has significantly affected 
on weed density under coconut cultivation. Though there was no any significant difference in weed density among the planting arrangements (T1, T2 and T3), Mucuna bracteata planted plots had significantly lower weed density than control (Table 3).

Table 3. Weed density of different treatments

\begin{tabular}{ccc}
\hline \multirow{2}{*}{ Treatments } & \multicolumn{2}{c}{$\begin{array}{c}\text { Weed Density } \\
\text { (No. of plants per } \mathbf{1 m}^{\mathbf{2}} \text { ) }\end{array}$} \\
\cline { 2 - 3 } & $\mathbf{1 ~ M A E}$ & $\mathbf{2 ~ M A E}$ \\
\hline T1 (2 rows) & $65^{\mathrm{b}}$ & $68^{\mathrm{b}}$ \\
T2 (3 rows) & $49^{\mathrm{b}}$ & $49^{\mathrm{b}}$ \\
T3 (4 rows) & $48^{\mathrm{b}}$ & $50^{\mathrm{b}}$ \\
T4 (Control) & $116^{\mathrm{a}}$ & $127^{\mathrm{a}}$ \\
\hline
\end{tabular}

$\overline{\text { Means with different letters within the same column }}$ represent significant differences at $p<0.05$ level; MAEMonths after establishment. T1-Coconut with $M$. bracteata in 2 rows, T2 - Coconut with M. bracteata in 3 rows, T3 - Coconut with M. bracteata in 4 rows, T4 Control / Coconut without M. bracteata

\section{Ground Cover}

Ground cover protects the soil from erosion and water loss and also it prevents the germination of weed seeds. This can be particularly useful on sloppy lands. It helps to reduce soil erosion during the rainfall condition as well as helps to conserve soil moisture providing resistance to the drought condition.

At 75 days after field establishing, T2 and T3 showed ground cover of $81.11 \%$ and $80.55 \%$ respectively. The treatments $\mathrm{T} 2$ and $\mathrm{T} 3$ showed significantly higher ground cover than T1 which was $38.88 \%$ (Table 4). This indicates that three row planting system has been able to provide same ground cover as in four rows planting system. Therefore, three row planting system is more efficient in terms of cost and labour.

Table 4. Ground cover of different planting arrangements

\begin{tabular}{cc}
\hline Treatments & Ground cover $(\%)$ \\
\hline T1 $(2$ rows $)$ & $38.88^{\mathrm{b}}$ \\
T2 $(3$ rows $)$ & $81.11^{\mathrm{a}}$ \\
T3 (4 rows) & $80.55^{\mathrm{a}}$ \\
\hline
\end{tabular}

Means with different letters within the same column represent significant differences at $p<0.05$ level; $T 1-$ Coconut with $M$. bracteata in 2 rows, T2 - Coconut with $M$. bracteata in 3 rows, T3 - Coconut with M. bracteata in 4 rows

\section{Soil Properties \\ Soil Bulk Density}

Soil bulk density is an indicator of soil porosity and soil compaction. According to the results, soil bulk density of all the treatments ranged from 1.18 to $1.45 \mathrm{Mg} / \mathrm{m}^{3}$ (Table 5). When bulk density is higher than $1.75 \mathrm{Mg} / \mathrm{m} 3$ it may restrict root penetration (Blake and Hartge, 1986). Mucuna bracteata planted plots had significantly lower bulk density than the control. The bulk density of T1was higher than those of $\mathrm{T} 2$ and T3. However, there was no statistically significant difference between the soil densities of $\mathrm{T} 2$ and $\mathrm{T} 3$. When $\mathrm{T} 2$ and $\mathrm{T} 3$ are considered, these treatments showed higher ground cover as well as higher organic carbon percentage. Soil organic carbon content mainly affects the reduction of bulk density. A higher ground cover also contributes to decrease the soil bulk density due to continuous addition of 
litter to the soil. It is considered to be favorable as it facilitates infiltration and reduced soil erosion.

Table 5. Soil Bulk Density (mean \pm SD) of Different Treatments

\begin{tabular}{cc}
\hline Treatments & $\begin{array}{c}\text { Bulk Density } \\
\left(\mathbf{M g} / \mathbf{m}^{\mathbf{3}}\right)\end{array}$ \\
\hline T1 (2 rows) & $1.32 \pm 0.03^{\mathrm{b}}$ \\
$\mathrm{T} 2$ (3 rows) & $1.24 \pm 0.03^{\mathrm{c}}$ \\
$\mathrm{T} 3$ (4 rows) & $1.18 \pm 0.06^{\mathrm{c}}$ \\
$\mathrm{T} 4$ (control) & $1.45 \pm 0.04^{\mathrm{a}}$ \\
\hline Means with different letters within the same column \\
represent significant differences at $p<0.05$ level; T1 - \\
Coconut with M. bracteata in 2 rows, T2 - Coconut with \\
M. bracteata in 3 rows, T3 - Coconut with M. bracteata in \\
4 rows, T4 - control/Coconut without M. bracteata
\end{tabular}

\section{Soil pH}

All treatments showed significant improvements in soil $\mathrm{pH}$ over control (T4). The soil $\mathrm{pH}$ ranged from 5.46 to 6.29 (Table $6)$. Though there was no any significant difference among T1, T2 and T3.

Table 6. Soil $\mathrm{pH}($ Mean \pm SD) after planting

\begin{tabular}{cc}
\hline Treatments & Soil pH \\
\hline T1 (2 rows) & $6.17 \pm 0.68^{\mathrm{a}}$ \\
T2 (3 rows) & $6.26 \pm 0.54^{\mathrm{a}}$ \\
T3 (4 rows) & $6.08 \pm 0.33^{\mathrm{a}}$ \\
T4 (control) & $5.50 \pm 0.35^{\mathrm{b}}$ \\
\hline
\end{tabular}

Means with different letters within the same column represent significant differences at $p<0.05$ level; $T 1-$ Coconut with M. bracteata in 2 rows, T2 - Coconut with M. bracteata in 3 rows, T3 - Coconut with M. bracteata in 4 rows, T4 - control / Coconut without M. bracteate

Increasing soil $\mathrm{pH}$ towards neutral range will increase the availability of soil nutrients (Rowell, 1994). The most appropriate $\mathrm{pH}$ range for coconut cultivation is 6 to $7 \mathrm{pH}$ level. The treatments $\mathrm{T} 1, \mathrm{~T} 2$ and $\mathrm{T} 3$ were in that range which is most suitable for coconut cultivation.

\section{Soil Organic Carbon}

All the treatments containing Mucuna bracteata, recorded higher levels of organic matter content than T4 (control). The results indicated that $\mathrm{T} 2$ had the highest organic carbon content $(1.08 \%)$ than other treatments (Table 7). There was no significant difference in organic carbon among the treatments, and it may be due to the short time period after the establishment to generate soil organic matter from litter. Samarappuli (2004) observed $1.1 \%$ organic carbon content under Pueraria and $2.8 \%$ with Mucuna under rubber plantations.

\section{Soil Total Nitrogen}

In coconut cultivation, nitrogen plays an important role in growth of the palm as well as the coconut yield. Urea is applied as the source of nitrogen to the soil. Mucuna bracteata is a leguminous cover crop which has the ability to fix atmospheric nitrogen. When considering all four treatments, there was a statistically significant difference among the treatments. The highest $\mathrm{N}$ content $(0.27 \%)$ was given by $\mathrm{T} 2$ while the lowest soil $\mathrm{N}$ content $(0.16 \%)$ was given by T1 (Figure 4). Herath et al., (2006) have found that total nitrogen in common coconut growing soils ranged from 0.02$0.13 \%$. 
Table 7. Soil Organic Carbon content (Mean \pm SD) after planting

\begin{tabular}{lc}
\hline Treatments & Organic Carbon $(\%)$ \\
\hline T1 (2 rows) & $0.99 \pm 0.18^{\mathrm{a}}$ \\
T2 (3 rows) & $1.08 \pm 0.14^{\mathrm{a}}$ \\
T3 (4 rows) & $1.07 \pm 0.23^{\mathrm{a}}$ \\
T4 (control) & $0.90 \pm 0.07^{\mathrm{a}}$ \\
\hline
\end{tabular}

Means with different letters within the same column represent significant differences at $p<0.05$ level; $T 1-$ Coconut with M. bracteata in 2 rows, T2 - Coconut with $M$. bracteata in 3 rows, T3 - Coconut with M. bracteata in 4 rows, T4 - control / Coconut without M. bracteata

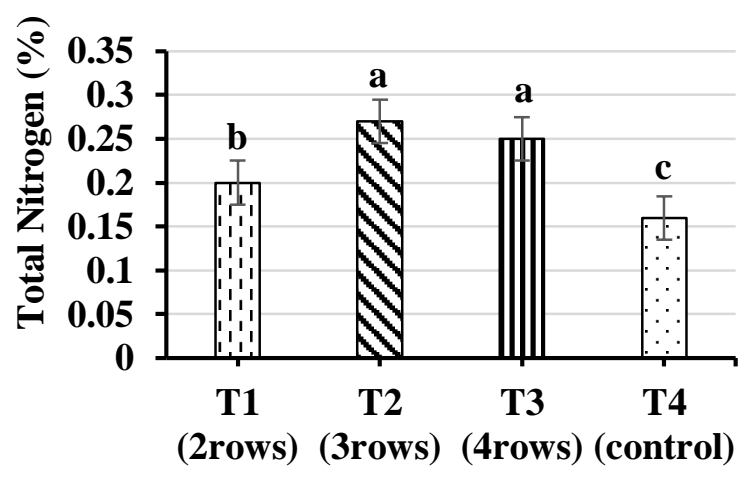

Treatments

Figure 4. Soil Total Nitrogen at 75 days after field establishment with different treatments

Treatment 2 and 3 had total $\mathrm{N}$ contents of $0.27 \%$ and $0.25 \%$ respectively. This content was a $42 \%$ and $31 \%$ increment compared to the initial value. There was no statistically significant difference between T2 and T3. Under well-grown cover-crop like this, there may be a possibility to reduce the amount of urea that is needed to apply for the coconut cultivation.

\section{CONCLUSION}

According to the results, it is clear that Mucuna bracteata can be well-grown as a cover crop under coconut in the intermediate zone of Sri Lanka based on its performances in total biomass production, ground covering ability, enhancing soil nitrogen and suppressing of weeds.

However, there was no significant difference between three-row-planting system of Mucuna bracteata and four-rowplanting systems of Mucuna bracteata with respect to ground cover, total biomass and soil nitrogen. Therefore, it can be concluded that Mucuna bracteata with three rows under coconut plantation in the Low Country Intermediate Zone of Sri Lanka is the best planting system to cover the ground with high biomass and it supplies high nitrogen content to the soil by minimizing cost of planting materials and labour.

In this research, soil sampling was done within a short period of time. However, it is important to see improvements in soil properties over a long period of time to further confirm the results.

\section{REFERENCES}

Abeywardena, V. (1971). Crop losses in coconut through button shedding and immature nut fall. Ceylon Coconut Planters' Review, 6: 97-105.

Anon, (2017). Annual report of central bank, Colombo, Sri Lanka. [Accessed $23^{\text {rd }}$ August 2018].

Blake, G. R. and Hartge, K. H. (1986). 
Methods of soil analysis. Physical and Mineralogical Methods. American Society of Agronomy, Madison, United States of America, 363-375.

Bermmer J.M. and Malvaney S. C. (1982). Nitrogen-Total. In: A. L. Page (Ed). Methods of Soil Analysis Part II. Chemical and Microbiological Methods. American Society of Agronomy. Wisconsin, USA.

Herath, H.M.I.K., Saumyakumara, A.P.A., Tennakoon, N.A. (2006). Soil fertility status of common coconut growing soil series in Sri Lanka. Journal of the Soil Science Society of Sri Lanka, 18: 3540; ISSSN 1015-0803

Mathews, C. (1998). Introduction and establishment of a new leguminous cover plant, Mucuna bracteata under oil palm in Malaysia. The Planter, 74: (868): 359-368.

Nelson, D. W. and Sommers, L.E. (1982). Total carbon, organic carbon, and organic matter. Methods of soil analysis part 3, 539- 579.

Olsen, S.R., Cole, C.V., Watanabe, F. S. and Dean, L. A. (1954). Estimation of available phosphorous in soils by extraction with sodium bicarbonate. United States Department of Agriculture, Washington.

Rowell, D. L. (1994). Soil Science, Methods and Applications. Longman Publisher Ltd.,169.

Samarappuli, L. (1992). Some agronomic aspects in overcoming moisture stress in Hevea brasiliensis. Indian Journal of Natural Rubber Research, 5: 127132.

Samarappuli, L., Karunadasa, P.,
Mithrasena, U. and Shantha, N. (2003). Mucuna bracteata: Ideal ground cover for efficient soil and water management in rubber cultivation. Tropical Agricultural Research and Extension, 6: 85-90.

Samarappuli, L., Karunadasa, P., Mithrasena, U. and Gunathilaka, T. (2004). Mucuna bracteata as a cover crop for rubber in Sri Lanka. In: Symposium in Plant and Crop Research, 87-94.

Samedani, B., Juraimi, A. S., Rafii, M. Y., Awadz, S. S., Anwar, M. P., and Anuar, A. R. (2015). Effect of cover crops on weed suppression in oil palm plantation. International Journal of Agriculture \& Biology, 17(2): 251260.

Senarathne, S. H. S. and Gunathilake, H. A. J. (2010). Weed management in mature coconut plantations in Sri Lanka. COCOS, 19: 93-100.

Vidhana-Arachchi. L. P., Mapa, R. B., Yapa, P. A. J. and Somapala, H. (1996). Characterization of soil physical properties in Andigama series in relation to coconut root growth. Tropical Agricultural Research, 8: 6477.

Vidhana-Arachchi, L.P., Yapa, P. A. J., Mapa, R.B. and Somapala, H. (2000). Soil physical constraints and their effect on morphological characters of coconut (Cocos nucifera L.) roots. Coconut Research and Development Journal XVI, 1: 14-33. 